\title{
THE INFLUENCE OF EDUCATION AND TRAINING AS WELL AS WORK EXPERIENCE ON THE ABILITY AND PERFORMANCE OF EMPLOYEES OF REGIONAL SECRETARIAT OF WEST PAPUA PROVINCE
}

\author{
${ }^{1}$ Yudha Prasetyo, ${ }^{2}$ Herningsih, and ${ }^{3}$ Anita Maharani \\ Universitas Terbuka \\ Email: ${ }^{1}$ guyana.perancis7@gmail.com, ${ }^{2}$ herningsih2018@gmail.com, ${ }^{3}$ anitamaharani@gmail.com
}

\begin{abstract}
Purpose: To analyze the effect of education and training and Work Experience on the workability and performance of employees of the Regional Secretariat of West Papua Province.

Design/methodology/approach: This research was conducted on the staff of the Regional Secretariat of West Papua Province with a population of 278. The sample used was 74 respondents. The determination of the sample was using a purposive sampling technique. The criterions set in the sampling are that the employee has status as a civil servant and has worked for at least 3 years. The independent variables in this study are education and training and work experience. The dependent variable is employee performance, while the intermediate variable is workability. Variable measurements are carried out using a Likert scale. Data analysis was performed using path analysis with the software used was Smart PLS 2.

Findings: Equations that could be formed from the results of the analysis were: $Z=0.476 X 1+0.292 X 2$; and $Y=0,345 X_{1}+0,115 X_{2}+0,243 Z$., where $Z=$ ability, $Y=$ performance, $X_{1}=$ education and training, and $X_{2}=$ work experience. Education and training had a positive and significant effect on employee workability, indicated by a path coefficient of 0.476 with a T-statistic value of 6.378; Work experience has a significant effect on employee workability, indicated by a path coefficient of 0.292 with a T-statistic value of 3.877; Education and training have a significant influence on employee performance as indicated by a path coefficient of 0.461 with a -statistic value of 1.958; Work experience has a significant effect on employee performance, indicated by a path coefficient of 0.186 with a T-statistic value of 3.877; Workability has a significant positive effect on employee performance, indicated by a path coefficient of 0.243 with a T-statistic value of 2.427. The advice that can be given is that every employee is always encouraged and allowed to be able to attend education and training. In work placement, the Regional Secretariat of West Papua Province must prioritize work experience so that the resulting performance can be maximized.
\end{abstract}

Research limitations/implications: Number of sample is relative small.

Practical implications: Result of this research can be used as references in increasing performance of the employee.

Originality/value: This research is original and conducting in West Papua Province.

Paper type: Research paper.

Keyword: Remuneration, Supervision, Employee Commitment, Employee Discipline, Job Performance.

Received: August $19^{\text {th }}, 2020$

Revised: September $12^{\text {nd }}, 2020$

Published: September $30^{\text {th }}, 2020$ 


\section{INTRODUCTION}

\section{A. Research Background and Conceptual Framework}

Employee performance is one of the things that is of serious concern at the Regional Secretariat of West Papua Province. West Papua Province. West Papua is a province of Indonesia located at the western tip of Papua Island. Human resources who are skilled, capable, and able to work following their work are needed by a government agency so that they can contribute to the success of achieving goals and improving services to these government organizations (Susanti, 2014). The fact that there are currently many employees who have performance below the expectations of the institution where they work. Many employees still have low performance. It can be seen in the workplace, some employees have a good performance, but some other employees still have a low performance. Employee performance achievements vary from one worker to another.

In the online newspaper papuabarat.antaranews.com dated April 7, 2019, news was published that the performance of the state civil apparatus (ASN) in the West Papua Provincial government is considered not to have increased significantly, even though the regions have implemented income repair allowances (TPP). Musa Kamudi, Assistant 1 for Government Affairs of the Regional Secretariat of West Papua Province, said that the TPP payment was aimed at making ASN more disciplined and improving their performance. However, the conditions in the field indicate that the existing conditions are still far from expectations. The local government has given TPP but the performance of ASN has not changed much for the better.

Employees with low performance will interfere with the process of achieving the goals of an organization, on the other hand, employees with high-performance achievements will make it easier to achieve organizational goals. Therefore, an organization must always pay attention to the performance achievement of each employee, including also paying attention to things that can improve employee performance. One of the things that can improve employee performance is that organizations can motivate employees by fulfilling employee needs, which include physiological needs such as drinking and food needs, security and safety needs, social needs, self-esteem needs, and self-actualization needs.

Education and training are important factors that must be considered to improve employee work performance. Education and training intended for employees can help employees to improve employee capabilities so that employees can solve problems encountered in the workplace. When problems in the workplace can be resolved properly, the employee's performance will certainly be better. The organization or leadership of an organization must always provide opportunities for its employees to take part in various training related to their field of work.

Education and training will be able to make a significant contribution to the organization because this activity will create superior and quality human resources which will eventually make employees able to compete with employees from other organizations. Almost all organizations have employee development programs and the provision of education and training is a manifestation of employee development programs. It is hoped that the education and training provided to these employees will be able to improve the workability of employees. Mulyasa (2006) explains that in general people with a higher level of education will have broader insights, mainly related to appreciation and understanding of productivity. Meanwhile, training can provide employees with the skills and knowledge required in their current field of work (Mondy, 2012).

There are various types of training held and attended by employees at the West Papua Provincial Secretary. Education and training for employees is a process of transferring knowledge and providing certain skills so that employees will be more skilled and able to carry out their duties and responsibilities properly. The existence of a job training education program is very helpful for companies to achieve organizational goals. Besides, education and training for employees are also useful for improving the quality, skills, abilities, and expertise of employees in carrying out their jobs. This will also have an impact on increased employee performance (Endayani \& Fatmasari, 2015) . The training activities carried out at the Regional Secretariat of West Papua Province were carried out several times so that every employee had the opportunity to participate in every training carried out. One thing that has been felt so far is that after the implementation of education and training activities, evaluation activities are not carried out in-depth to determine the effectiveness of the training activities that have been carried out.

In general, the work capacity of the people in West Papua, including the State Civil Servant (ASN) is still not optimal. The Human Development Index in West Papua is generally higher than the HDI in Papua, however, when compared to the average National HDI, the HDI in West Papua is still lower. The condition also describes the work capacity of the people in West Papua, which is generally still lower than in other regions in Indonesia.

Apart from education and training (Diklat), employee work experience is one of the determinants of optimal performance achievement. Mangkuprawira (2015) states that employee experience at work is an

The Influence Of Education And Training As Well As Work Experience On The Ability

Page | 262 
accumulation of success and failure and is a combination of strengths and weaknesses in carrying out their work. Gibson, Ivancevich, \& Donelly (2015) argues that employees who have work experience will always be better at responding to all events and situations than employees who do not have work experience. This condition in the end can result in better performance.

The description that has been presented above shows that currently, the performance of employees at the Regional Secretariat of West Papua Province is not yet optimal, even though the government has provided incentives to employees. Therefore, it is important to conduct research on performance and the factors that influence it. Based on the results of the analysis of the report, two factors are predicted to affect the performance of West Papua Secretariat employees and have been included in the planning of the West Papua Provincial Secretariat, namely Education and Training and work experience.

Based on the above problems, the objectives of this study are:

1. To analyze the effect of education and training on the workability of employees.

2. To analyze the effect of work experience on the workability of employees.

3. To analyze the effect of education and training on employee performance.

4. To analyze the effect of work experience on employee performance.

5. To analyze the effect of ability on employee performance.

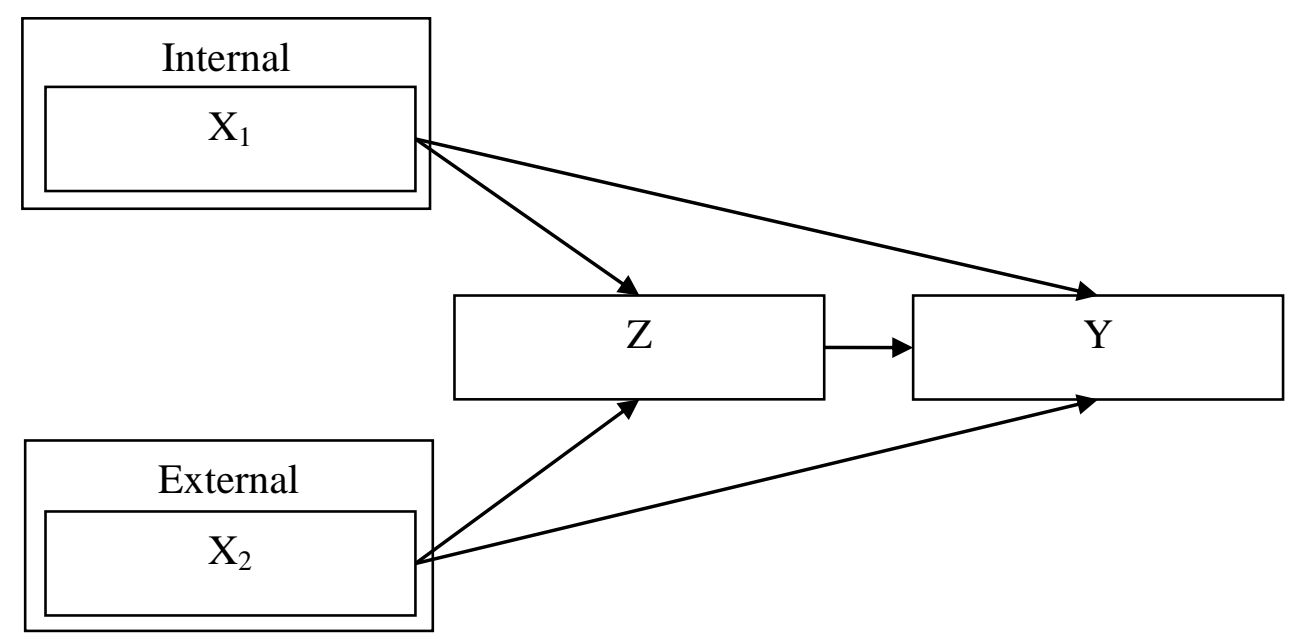

Figure 1. Conceptual Framework

Information:

$\mathrm{X}_{1}$ : Education and Training

$\mathrm{X}_{2}$ : Work Experience

Z: Ability

Y: Performance

The hypotheses that can be proposed in this study are:

$\mathrm{H}_{1}$ : Education and training (X1) have a significant positive effect on employee workability (Z).

$\mathrm{H}_{2}$ : Work experience (X2) has a significant positive effect on the workability of employees (Z).

$\mathrm{H}_{3}$ : Education and training (X1) have a significant positive effect on employee performance (Y).

$\mathrm{H}_{4}$ : Work experience (X2) has a significant positive effect on employee performance (Y).

$\mathrm{H}_{5}$ : Ability (Z) has a significant positive effect on employee performance (Y)

\section{METHODOLOGY}

The population in this study were all employees of the Regional Secretariat of West Papua Province, totaling 278 employees. The sample used in this study were 74 employees of the Secretariat of West Papua Province. Determination and sampling using a purposive sampling technique, a procedure of determination, and sampling in which elements are selected from the target population based on their suitability with the objectives of the study and also the criteria set. The criteria set in the sampling are that the employee has a civil servant status and has worked for at least 3 years. The research was conducted at the Regional Secretariat of West Papua Province, between March 2019 - July 2020.

The variables in this study consist of:

1. Independent variable

a. Education and Training (X1) 
The indicators are (Heidjrachman and Husnan, 2016: 75):

1) The training material is understandable

2) Training following the task

3) Training can improve skills

4) The results of training are applied in the workplace

5) Training can improve work results

b. Work experience (X2)

Work experience indicators, namely (Room, 2014: 6):

1) Length of time/years of service

2) The level of knowledge and skills possessed

3) Mastery of work and equipment

2. The dependent variable, employee performance $(\mathrm{Y})$

The indicators of employee performance are (Sudarmanto, 2018: 12):

a. Employees have accuracy and neatness in completing work.

b. Employees have the speed to get work done.

c. Employees can complete work without the need for supervision.

d. Employees can cooperate with colleagues.

e. Employees can bring a better working atmosphere.

3. Intermediate Variable, ability (Z)

The indicators are Rudhaliawan \& Mahmudhitya (2013):

a. Can solve problems or difficulties at work

b. Understand the work that is an obligation.

c. Can get work done without making mistakes.

d. Ready to accept and carry out more difficult or difficult work.

e. Be disciplined at work.

f. Have job responsibilities following the field of work.

Data analysis in this study used a path analysis approach using smart PLS software. The advantages of smart PLS software include that the Smart-PLS approach is considered powerful because it is not based on various assumptions, the number of samples required in the analysis is relatively small and the data in the Smart-PLS analysis does not have to have a normal distribution.

The stages carried out in the analysis are:

1. Draw a path diagram model

2. Evaluate the Goodness of Fit Outer Model

3. Evaluate the Inner Model Goodness-of-fit

The next stage is to test the hypothesis. In this study, a significant level $(\alpha)=0.05$ was used. The provisions in acceptance of the Hypothesis are as follows:

1. If the value of the $t$-count $<\mathrm{t}$-table, then the hypothesis is rejected.

2. If the value of the $t$-count $>t$-table, then the hypothesis is accepted.

\section{RESULTS AND DISCUSSION}

The result and discussion must be written in the same part. They should be presented continuously start from the main result to the supporting results and equipped with a discussion. The unit of measurement used should follow the prevailing international system. All figures and tables are placed separately at the end of manuscript pages and should be active and editable by the editor. 


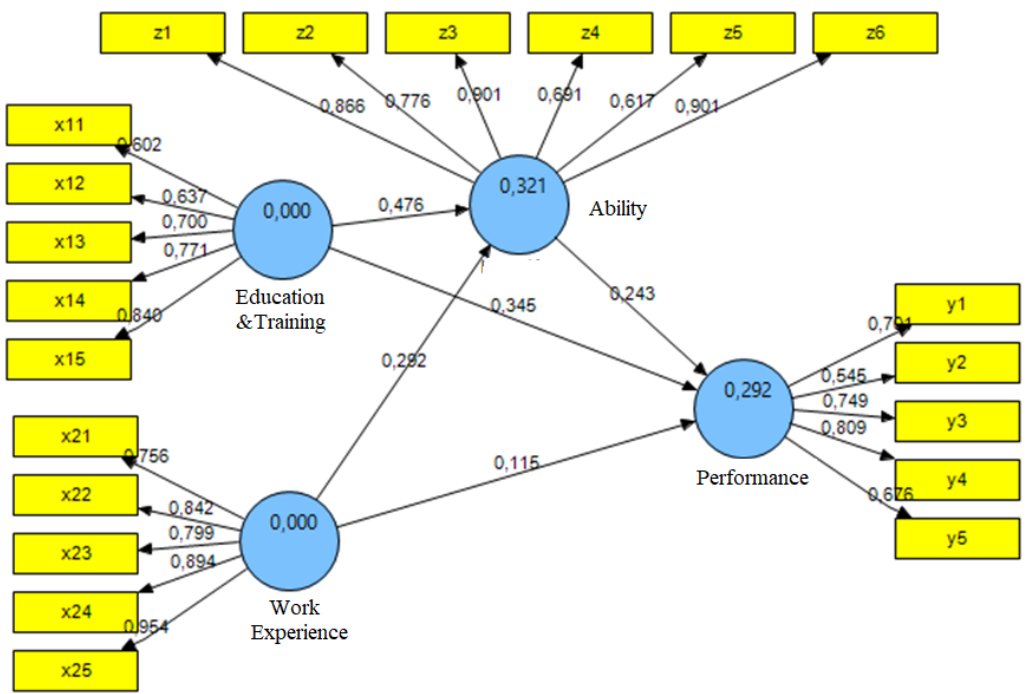

Figure 2. Path Analysis Results

Based on the model above, the equation can be made as follows:

$\mathrm{Z}=0.476 \mathrm{X} 1+0.292 \mathrm{X} 2$

$\mathrm{Y}=0.345 \mathrm{X} 1+0.115 \mathrm{X} 2+0.243 \mathrm{Z}$

Information:

$\mathrm{Z}=$ ability

$\mathrm{Y}=$ performance

$\mathrm{X} 1$ = education and training

$\mathrm{X} 2$ = work experience

Based on the path diagram above, an explanation of the numbers on the connecting line can be made between the independent variable and the dependent variable as follows:

1. The path coefficient value from education and training to the ability variable $=0.476$. An increase in one unit education and training will increase the ability by 0.476 .

2. The path coefficient value from the work experience variable to the ability variable $=0.292$. An increase in the one unit work experience variable will increase the ability by 0.292 .

3. The path coefficient value from the education and training variable to the performance variable $=0.345$.

An increase in the education and training variables by one unit will increase the performance by 0.45 .

4. The path coefficient value from the work experience variable to the performance variable $=0.115$. An increase in the work experience variable by one unit will increase motivation by 0.115 .

5. The value of the path coefficient from the ability variable to the performance variable $=0.243$. An increase in the ability variable by one unit will increase the performance by 0.243 .

Next, the calculation of the R-square is carried out. R square shows the ability of research variables in explaining performance (Kuncoro, 2012). Based on data processing with PLS, the resulting coefficient of determination (R-square) is as follows:

Table 1. Value of R-square Model

\begin{tabular}{|l|c|}
\hline \multicolumn{1}{|c|}{ Variable } & R Square \\
\hline Ability & 0,321 \\
\hline Performance & 0,292 \\
\hline Work Experience & - \\
\hline Education and training & - \\
\hline
\end{tabular}

The R square value for ability is 0.321 . This value means that the percentage of performance that can be explained by education and training and work experience is $32.1 \%$.

The R square value for performance is 0.292 . This value means that the percentage of performance that can be explained by education and training, work experience, and ability is $29.2 \%$.

The goodness of fit assessment in the PLS model can be seen from the Q2 value. The value of Q2 has the same meaning as the coefficient of determination (R-square / R2) in the regression analysis. The higher 
$\mathrm{R} 2$, the model can be said to be more fit with the data. From the table above, it can be seen that the value of Q2 is as follows:

$$
\begin{aligned}
\text { Q2 value } & =1-((1-0,321) \times(1-0,292)) \\
& =1-(0.679) \times(0.708)) \\
& =1-0.481 \\
& =0.519
\end{aligned}
$$

In this research model, the total R-square value generated is 0.519 , meaning that the amount of diversity in the research data that can be explained by the structural model is $50.4 \%$, while the remaining $49.6 \%$ is influenced by other factors.

The final stage in PLS analysis is to prove the research hypothesis. Partial Least Square analysis also produces path coefficients on the inner model:

Table 2. Inner Model Results

\begin{tabular}{|l|c|c|c|}
\hline \multicolumn{1}{|c|}{ Effect } & $\begin{array}{c}\text { Original } \\
\text { Sample }\end{array}$ & $\begin{array}{c}\text { Sample } \\
\text { Mean }\end{array}$ & T Statistics \\
\hline Education \& training -> ability & 0,476 & 0,480 & 6,378 \\
\hline Education \& training -> performance & 0,461 & 0,469 & 5,268 \\
\hline Ability -> performance & 0,243 & 0,228 & 2,427 \\
\hline Work experience -> ability & 0,292 & 0,293 & 3,877 \\
\hline Work experience -> performance & 0,186 & 0,212 & 2,134 \\
\hline
\end{tabular}

The value of the $\mathrm{T}$ table used in this study is $=1.993$. From Table 2 above, a structural model can be prepared to prove the research hypothesis as follows:

1. The effect of education and training on abilities

Based on the data presented in Table 2, it can be explained that the influence of the education and training variables on ability is 0.476 with a T-statistic value of 6.378 which is greater than 1.993 ( $\mathrm{T}$ table, $\square=0.03$, DK = 72). This situation shows that education and training have a significant effect on employee abilities. The effect that education and training have on ability is positive. The positive influence of this study shows that the better the quality of education and training received by employees, the better the employee's ability level. On the other hand, the lower the education and training received by the Regional Secretariat of West Papua Province, the lower the level of employee capability.

The results of this study support the results of previous studies which show that (Rudhaliawan \& Mahmudhitya, 2013) shows that training has a significant effect on the workability of employees. Another study that has resulted in line with research is the research conducted by (Pamungkas, Hamid, \& Prasetya, 2017) education affects, but not significantly, on the Job Ability variable.

Employee education and training is the focus of continuous efforts to improve employee skills. Training provides employees with the knowledge and skills needed for their current jobs (Mondy, 2012). Training has a significant effect on ability, indicating that training will provide opportunities for employees to develop new skills and abilities at work so that what is known and mastered now and in the future can help employees understand what should be done and provide opportunities to increase knowledge and expertise.

2. The effect of work experience on abilities

Based on the data presented in Table 2, it can be explained that the influence of the work experience variable on ability is 0.292 with a T-statistic value of 3.877 which is greater than 1.993 . This situation shows that work experience has a significant effect on employee abilities. The effect that work experience has is positive. An increase or decrease in work experience affects increasing and decreasing the ability of employees.

The results of the study support the research results of Pamungkas et al., (2017)which shows that work experience has a significant effect on Work Ability. Employee work experience shows the level of mastery of skills skills. Skills can be obtained from the work experience of employees doing this type of work repeatedly (Simanjuntak, 2017). An employee's workability can be influenced by how long an employee's experience is. Employee work experience shows the level of mastery of skills (soft skills) of employees. Work experience is the mastery of knowledge and skills of employees as measured by the length of the service period, the level of knowledge and skills possessed by employees. 
3. Effect of education and training on performance

Based on the data presented in Table 2, it can be explained that the influence of the education and training variables on performance is 0.461 with a T-statistic value of 5.268 which is greater than 1.993. This situation shows that education and training have a significant effect on employee performance. The effect generated by education and training on employee performance is positive, which means that if education and training are carried out better, the employee's performance will also be better. Conversely, if education and training are not carried out properly, the employee's performance will also get lower.

This study supports the results of Rudhaliawan \& Mahmudhitya (2013) research which shows that education and training have a positive and significant relationship with employee performance. Another study with results in line with this study was conducted by Gede, Putra, \& Yuniari (2013) which showed that education had a positive effect on employee work performance.

Education and training is an effort to increase the knowledge and skills of an employee to do a certain job. The existence of increasing the skills, knowledge, insights, and attitudes of employees on their duties through training programs that have been implemented within the organization can improve the performance of the employees of the organization (Pakpahan \& Saputra, 2014). With the existence of education and training, employees will be able to work more effectively and efficiently, especially to deal with changes that occur such as changes in technology, changes in work methods, also demanding changes in attitudes, behavior, skills, and knowledge.

4. The effect of work experience on performance

Based on the data presented in Table 2, it can be explained that the influence of the work experience variable on performance is 0.186 with a T-statistic value of 2.134 which is greater than 1.993 . This situation shows that work experience has a significant effect on employee performance. Changes that occur in work experience will have an impact on the work performance of the West Papua Provincial Secretariat employees.

This study supports the results of previous studies conducted by Pamungkas et al. (2017)which shows that work experience has a significant influence on employee performance. The length of experience of employees in the field of work occupied is one of the factors determining the influence of employee work experience on their performance. This work experience can be seen from the skills and mastery of employee knowledge as measured by the length of work, the level of knowledge and skills possessed by employees. This work experience can only be obtained by working in a workplace (Pamungkas et al., 2017).

Work experience is an important factor in shaping performance, in other words, performance is influenced by how long an employee's experience is. In improving employee performance, employee experience is needed. Employee work experience shows the level of mastery of employee skills which will ultimately improve employee performance.

5. Effect of ability on performance

Based on the data presented in Table 2, it can be explained that the effect of the ability variable on performance is 0.243 with a T-statistic value of 2.427 which is greater than 1.993. This situation shows that the ability has a significant effect on employee performance. The effect generated by ability on performance is positive. The positive influence in this study shows that the higher the ability of the West Papua Provincial Secretariat employees, the better the performance of the West Papua Provincial Secretariat employees. Conversely, the lower the staff of the West Papua Provincial Secretariat, the lower the employee's performance.

This study supports the results of research conducted by Pamungkas et al. (2017) which shows that workability has a significant effect on employee performance. Another study with results in line with this study was conducted by Rudhaliawan \& Mahmudhitya (2013)which showed that workability had a significant effect on employee performance.

Employee workability is one of the factors that affect their performance. When a company accepts an employee to occupy a certain position in the organization, a selection process is first carried out to find employees with the ability to meet the demands of their work. An organization will also carry out employee development activities to prepare these employees to be able to move and play a role in the organization. This employee development activity is carried out by first assessing the work results or employee performance for the work assigned to them. So the purpose of training and development is basically to increase the mastery of skills and knowledge of employees for performance improvement (Pakpahan \& Saputra, 2014).

Ability is an important factor in determining performance. Ability is the potential that is in a person to do so that it allows someone to be able to do the job or not be able to do the job. Workability greatly affects the quality or weight of the work achieved by an employee. Workability greatly determines the performance of employees in an organization. 
The results of testing these seven hypotheses can be summarized in Table IV.12 below.

Table 3. Summary of Hypothesis Testing Results

\begin{tabular}{|c|l|r|c|c|}
\hline Hypothesis & \multicolumn{1}{|c|}{ Hypothesis Statement } & $\begin{array}{c}T \\
\text { statistic }\end{array}$ & $\begin{array}{c}\text { Cut } \\
\text { off }\end{array}$ & Conclusion \\
\hline $\mathrm{H}_{1}$ & $\begin{array}{l}\text { Education and training have a significant positive } \\
\text { effect on employee employability. }\end{array}$ & 6,378 & 1,993 & $\begin{array}{c}\text { Hypothesis } \\
\text { accepted }\end{array}$ \\
\hline $\mathrm{H}_{2}$ & $\begin{array}{l}\text { Work experience has a significant positive effect on } \\
\text { employee workability. }\end{array}$ & 3,877 & 1,993 & $\begin{array}{c}\text { Hypothesis } \\
\text { accepted }\end{array}$ \\
\hline $\mathrm{H}_{3}$ & $\begin{array}{l}\text { Education and training have a significant positive } \\
\text { effect on employee performance }\end{array}$ & 5,268 & 1,993 & $\begin{array}{c}\text { Hypothesis } \\
\text { accepted }\end{array}$ \\
\hline $\mathrm{H}_{4}$ & $\begin{array}{l}\text { Work experience has a significant positive effect on } \\
\text { employee performance }\end{array}$ & 2,134 & 1,993 & $\begin{array}{c}\text { Hypothesis } \\
\text { accepted }\end{array}$ \\
\hline $\mathrm{H}_{5}$ & $\begin{array}{l}\text { The ability has a significant positive effect on } \\
\text { employee performance. }\end{array}$ & 2,427 & 1,993 & $\begin{array}{c}\text { Hypothesis } \\
\text { accepted }\end{array}$ \\
\hline
\end{tabular}

The implications of the results of this study are:

1. Practical Implications

The results of this study are expected to be able to make a positive contribution, especially for the Regional Secretariat of West Papua Province. The results showed that the education and training implemented by the ranks of the Regional Secretariat of West Papua Province had a significant effect on the ability and performance of employees. Work experience also shows a positive and significant influence on workability and employee performance. Therefore, efforts are needed to improve education and training as well as employee work experience. This increase is carried out on the indicators that have the lowest scores.

a. Education and training

Based on the results of the data analysis that has been carried out, it can be seen that education and training have a positive and significant effect, both on workability and employee performance. The influence is given by education and training, both on workability and performance, is greater than the effect of work experience. This can be seen from the larger path coefficient of the education and training variables compared to the work experience variable. Therefore, the Regional Secretariat of West Papua Province must pay attention to the education and job training provided to its employees. Each employee must be included in training following the field of work occupied by each employee. Before the implementation of education and training, the Regional Secretariat of West Papua Province also needs to analyze the condition of the human resources that will be given training. Thus the education and training provided to employees will be more effective because they are carried out on target.

Educational and training activities provided by employees must be carried out by implementing management functions (Bateman \& Snell, 2008). There must be planning or planning, including evaluation of the condition of employees before training, targets to be achieved with education and training, training concepts, and resources to be used in research. Education and training activities must also go through the stages of organizing, leadership (leading), to controlling (controlling). In this controlling stage, there is one thing that has so far been neglected by the Regional Secretariat of West Papua Province, namely monitoring, including the evaluation of whether education and training have been carried out properly and the targets that have been set have been achieved or not.

b. Work experience

In this study, work experience can have a positive and significant impact on the workability of employees. Work experience also has a significant influence on employee performance. Seeing this existing condition, the Regional Secretariat of West Papua Province needs to continue to evaluate the work experience of each employee. The work experience possessed by each employee should also be used as a reference in the work placement process for each employee so that the work experience that has been owned can support employee performance.

The current work experience of employees has been used as a reference in employees, but the working period is used as the main reference, while the characteristics of the work occupied in the past have not become the main consideration in placing employees in a certain position. The period of work is still the main consideration, not the characteristics of the work occupied in previous periods. Therefore, in the future, it is necessary to further study the characteristics of each job that has been engaged in in the past as one of the main considerations in assigning employees to a new position. 
c. Ability

The ability to have a position as an intermediary variable, namely being an intermediary for the effect of education and training and work experience on performance. In research, it can be seen that the ability has a significant positive effect on employee performance. Therefore, the workability of employees needs to be continuously improved. Increasing the workability of employees can be done by providing education and training, work experience, or in other ways.

2. Theoretical Implications

The research results have been able to enrich references in the field of human resource management. This study shows that incentives or allowances do not always have a significant impact on employee performance, as evidenced by the fact that the West Papua Provincial Government has provided allowances to employees, but employee performance has not increased as expected.

This study provides evidence that education and training as well as work experience have a significant effect on improving employee performance. Employees who receive proper education and training will be able to improve their abilities which in turn will have a significant impact on employee performance. Employees with high abilities will be able to produce good work.

Work experience is also a determinant of employee performance. Employees who have good work experience, seen from the length of work, will have an impact on the good performance of these employees. This work experience will first effect increasing the workability of employees. This certainly makes sense, employees who work in a certain field of work, their ability in that field the longer it will certainly be better. This condition will certainly have an impact on the employee's work which is also getting better.

The results of this study are in line with the theory which states that training and development are basically to increase the mastery of skills and knowledge of employees for performance improvement (Pakpahan \& Saputra, 2014). The results of the study have also strengthened the results of previous studies which state that education and training and work experience will have a significant impact on workability and employee performance (Pamungkas et al., 2017, Rudhaliawan \& Mahmudhitya, 2013, Endayani \& Fatmasari, 2015). Theoretically, the research results prove human resource management theories that have been put forward by experts and also support previous studies that have been conducted.

\section{CONCLUSION}

This study discusses the effect of education and work experience on the workability and performance of the West Papua Provincial Secretariat employees. The conclusions that can be drawn from this research are: Education and training have a positive and significant effect on the workability of employees. This is indicated by the path coefficient value of 0.476 with a T-statistic value of 6.378 which is greater than 1.993 ( $\mathrm{T}$ table, $\square=0.05, \mathrm{DK}=72$ ). This existing condition shows that an increase in the quality of education and training will be able to increase the ability of employees. Education and training will provide knowledge and skills for employees which in turn will make the employees' abilities better.

Work experience has a positive and significant influence on the workability of employees. This is indicated by the path coefficient of 0.292 with a T-statistic value of 3.877 which is greater than 1.993 . This existing condition shows that the more work experience an employee has, the longer the employee works in a certain field, the better the ability in that field of work will be.

Education and training have a positive and significant impact on employee performance. This is indicated by the path coefficient of 0.461 with a T-statistic value of 1.958 which is greater than 5.268. This situation shows that the better the education and training provided to employees, the better the employee's performance will be. Employees who take part in education and training, especially education and training following the field of work they are engaged in, will make their work output better.

Work experience has a positive and significant effect on employee performance. This is indicated by the path coefficient of 0.186 with a T-statistic value of 3.877 which is greater than 1.993 . This shows that the better the employee's work experience, the better the employee's performance will be. The longer an employee works in a certain field, the better the employee's performance in that field will be.

Workability has a positive and significant effect on employee performance. This is indicated by the path coefficient value of 0.243 with a T-statistic value of 2.427 which is greater than 1.993 . This condition shows that the better the workability of an employee, the better the performance that can be achieved. 
Suggestions that can be given in this research are:

1. Education and training have a greater influence than work experience on workability and employee performance. Therefore, every employee in the Regional Secretariat of West Papua Province is always encouraged and allowed to be able to continue education and training to a higher level. Besides, it is necessary to evaluate to determine the effectiveness of the education and training provided. This effectiveness can be seen by comparing the training targets and objectives and the achievements produced by the training participants. If the training has not been effective, it is necessary to make improvements to the education and training activities carried out so that these activities are more effective.

2. In this study, work experience has a direct influence on employee performance and also has a positive and significant effect by first passing the modification variable, namely workability. Therefore, in providing work experience to employees, the Regional Secretariat of West Papua Province must prioritize work experience in carrying out employee job placements. Work experience in question is the work experience of an employee that has relevance or relevance to the new field being handled.

\section{ACKNOWLEDGMENTS}

Acknowledgments of people, grants, funds, etc. should be placed in a separate section on the title page. The names of funding organizations should be written in full.

\section{REFERENCES}

Bateman, thomas S., \& Snell, S. A. (2008). Manajemen: Kepemimpinan dan kolaborasi dalam dunia yang kompetitif (Ed.7, cet.). Jakarta: Salemba Empat.

Endayani, \& Fatmasari. (2015). Pengaruh Pelatihan Kerja Terhadap Kemampuan Kerja Dan Kinerja Karyawan (Studi Pada PT. BPRS Bumi Rinjani Kepanjen). Jurnal Administrasi Bisnis, 25(1). Retrieved from http://administrasibisnis.studentjournal.ub.ac.id/index.php/jab/article/view/983

Gede, I., Putra, G. P., \& Yuniari, M. (2013). Pengaruh Pendidikan dan Pelatihan terhadap Prestasi Kerja Karyawan Bagian Fixed Phone Sales pada PT.Telekomunikasi.Tbk Denpasar. In E-Jurnal Manajemen Universitas Udayana (Vol. 2). Universitas Udayana.

Gibson, J. L., Ivancevich, J. M., \& Donelly. (2015). Organization: Structure, Process, Behavior. Dallas: Business Publication.

Kuncoro, M. (2012). "Masalah, kebijakan, dan politik ekonomika pembangunan. Jakarta: Erlangga.

Mangkuprawira, T. S. (2015). Bisnis Manajemen dan Sumber Daya Manusia. Bogor: IPB Pres.

Mondy, R. W. (2012). Human resource management (12th ed., ed.). Boston: Pearson education.

Mulyasa, E. (2006). Menjadi kepala sekolah profesional. Bandung: Remaja Rosdakarya.

Pakpahan, \& Saputra, E. (2014). Pengaruh Pendidikan dan Pelatihan terhadap Kinerja Pegawai (Studi pada Badan Kepegawaian Daerah Kota Malang). Jurnal Administrasi Publik, 2(1), 116-121. Retrieved from http://administrasipublik.studentjournal.ub.ac.id/index.php/jap/article/view/347/193

Pamungkas, A. D. P., Hamid, D., \& Prasetya, A. (2017). Pengaruh Pendidikan Dan Pengalaman Kerja Terhadap Kemampuan Kerja Dan Kinerja Karyawan (Studi pada Karyawan PT. INKA (Persero)). Jurnal Administrasi Bisnis, 43(1), 96-103. Retrieved from http://administrasibisnis.studentjournal.ub.ac.id/index.php/jab/article/view/1702

Rudhaliawan, \& Mahmudhitya, V. (2013). Pengaruh Pelatihan Terhadap Kemampuan Kerja Dan Kinerja Karyawan(Studi Pada Karyawan PT. Telkom Indonesia, Tbk Kandatel Malang). Jurnal Administrasi Bisnis, $4(2)$. Retrieved from http://administrasibisnis.studentjournal.ub.ac.id/index.php/jab/article/view/180

Simanjuntak, P. J. (2017). Pengantar Ekonomi Sumber Daya Manusia. Jakarta: Lembaga Penerbit Fakultas Ekonomi UI.

Susanti, S. H. (2014). Studi Tentang Penilaian Prestasi Kerja Pegawai. EJournal Administrasi Negara, 2(4), 1977-1990. 